Volume LI - REVISTA DE HISTORIA - Ano XXVI

\title{
ARTIG0S
}

\section{AS ARTES LIBERAIS NA IDADE MÉDIA.}

\section{RUY AFONSO DA COSTA NUNES}

do Dopartamento de Filosofia e Ciências da Educação da Faculdade de Educação da Universidade de São Paulo.

A consideração sobre o estudo das Artes Liberais na Idade Média precisa ser dividida em duas partes radicalmente distintas, a saber, a situação desse estudo desde o fim do mundo antigo até ao século XII, e depois, dessa época até ao advento do humanismo renascentista no fim do século XIV.

Os estudiosos medievais herdaram dos romanos a sua cultura, bem como as tradições pedagógicas. Os romanos, por sua vez, durante o período helenístico, absorveram e difundiram através do seu Império o legado educacional dos gregos. Sabe-se que Platão no livro VII da República distingue as logikai tecnai das bánausoi tecnai, isto é, as artes racionais próprias dos homens livres, e as artes mecânicas ou servis, próprias dos trabalhadores manuais ou escravos. Mostra Platão que a aritmética, a geometria, a astronomia e a harmonia são disciplinas propedêuticas à ciência da dialética, que permitirá à alma passar à contemplação da suprema Idéia do Bem. Alem disse, no Protágoras diz ainda Platão, que os jovens, quando já se julgam livres do estudo das artes, são compelidos pelos sofistas ao aprendizado do cálculo, da astronomia, da geometria e da música. Os sofistas, do seu lado, cultivaram com empenho a gramática, a retórica e a arte das discussões. Mas, enquanto Platão formulou e representou ao vivo o ideal pedagógico da filosofia como a meta dos estudos, seu contemporâneo Isócrates atraia para Atenas multidões de alunos, aos quais ensinava os segredos da retórica e da persuasão política. Desse modo, surgiram os dois modelos e paradigmas da formação escolar: de um lado, o ideal platônico que reduz todas as disciplinas literárias e científicas a simples estudos proemiais à filosofia e, do outro lado, o ideal isocrático, de acordo com o qual o importante era dar aos jovens boa formação literária, ensinando-lhes a bem falar, exprimir-se com clareza e a comunicar-se com os ouvintes por meio de palavras adequadas e de belas expressões. Pois bem, foi esse ideal retórico de Isócrates que vingou entre os romanos, e que Cícero e Quintiliano transmitiram, através de suas obras, aos estudiosos da Idade Média e, mais tarde, aos humanistas do Renascimento italiano. Para Platão, a filosofia 
era a sabedoria tomada como alvo último dos estudos, e para Isócrates a meta dos trabalhos escolares era a eloquência valorizada devido ao seu alcance prático, ao seu papel na vida política e, no caso dos romanos, à sua importância para as lides do forum.

Acresce que, para Isócrates, a filosofia só entraria no curso dos estudos cum grano salis, a título de elemento formativo, mas de modo algum como o objetivo supremo, segundo a concepção de Platão.

Durante o periodo helenístico, que se iniciou com a conquista da Grécia e do mundo grego pelos romanos, multiplicaram-se as obras dedicadas às várias disciplinas encíclicas que compunham o currículo médio da formação escolar correspondente ao nosso moderno curso secundário. O primeiro autor que procurou, à imitação de obras gregas congêneres, apresentar aos romanos o conteudo das disciplinas encíclicas foi Varrão nos seus Nove Livros das Disciplinas que compreendiam: a gramática, a retórica, a dialética, a geometria, a aritmética, a astronomia, a música e a arquitetura.

Entre os transmissores da cultura antiga à Idade Média as disciplinas matemáticas eram sempre apresentadas de acordo com as fontes gregas em que se abeberavam aos seus autores, fosse um Terêncio Varrão nos Nove Livros das Disciplinas no século I a. C., fosse um Boécio, no início do século $\mathrm{V}$ de nossa era, nos seus manuais de aritmética, música e geometria. Quanto às disciplinas literárias, a gramática abrangia tanto o estudo da língua latina como as obras literárias nesse idioma, e a retórica, que trata da arte de bem falar, ligava-se estreitamente à dialética, a arte de pensar corretamente e de discutir com acerto. Em obras como a de Varrão ou nos escritos lógicos de Boécio vinham a lógica aristotélica e a estoica esquematicamente compendiadas para uso dos estudantes, enquanto para a retórica passaram a valer as obras elegantes e eloquentes de Cícero. No tocante à gramática pura, Donato, professor de retórica em Roma na metade do século IV, redigiu duas sendo a inferior para os principiantes, e a superior para os alunos mais adiantados. Alem disso, concorreram para o enriquecimento dessa disciplina os gramáticos Charisius e Diomedes na segunda metade do século IV mas principalmente Prisciano que, no fim do século V, redigiu os dezoito livros das suas Institutiones gramaticae, de tal forma que veio a ser, junto com Donato, o autor preferido para os estudos de gramática durante a Idade Média. No entanto, quem realizou a melhor compilação sobre as artes liberais em obra que se tornou clássica nas escolas medievais foi o africano Martianus Capella, contemporâneo de Santo Agostinho e que escreveu em Cartago, por volta de 420 , os Satyricon Libri IX ou as Núpcias de Filologia com Mercúrio. Dos nove livros em que a obra se divide, nos dois primeiros Marciano 
descreve de forma imaginosa o casamento do deus Mercúrio com a douta senhorita Filologia. O olímpico patrono da eloquência estava ansioso por convolar núpcias, mas seu pedido de casamento fora sucessivamente recusado por distintas deidades, tal como Sofia, Mântica ou Psique. Por recomendação de Virtude, vai Mercúrio aconselhar-se com Apolo, que the aponta Filologia como excelente partido. Firmada a escolha, Virtude, Apolo e Mercúrio voam para o palácio de Júpiter, a fim de obter o seu consentimento. Convoca-se, então, um concílio dos deuses. Aprova-se o noivado e resolve-se que a noiva deve ser elevada à categoria divina. No término do primeiro Livro, "uma senhora séria e muito ilustre, que se chamava Filosofia" foi incumbida de anunciar os proclamas, enquanto Júpiter se levantava do trono e os deuses debandavam para as suas moradas (1).

No segundo Livro aparece Filologia, satisfeita mas temerosa de tanta honra, a ser preparada para as bodas por sua mãe Frônesis que a enfeita, e a ser estimulada pelas quatro virtudes cardeais e encorajada pelos beijos das três Graças, enquanto as Musas entoavam belos cânticos. Chega, então, Atanásia, filha de Apoteose, para levar a noiva até ao Céu. Antes, porem, toca-lhe de leve no peito, que apresenta uma grande inchação.

Assim, não pode ser, diz Atanásia. Não poderás ser deificada, Filologia, se não te livrares primeiro do que te enche o peito. A noiva comovida entra a vomitar uma porção de volumes, de várias encadernações e de diferentes assuntos. Em suma, num instante Filologia ficou esbelta, apesar de pálida. Mas, à medida que tanta boa literatura era expelida pela erudita noiva, os livros iam sendo recolhidos por várias mocinhas, das quais, diz Marciano, umas eram Artes, e outras Disciplinas, ajudadas nessa faina pelas musas Urânia e Calíope. Depois disso, a noiva sorve o licor da imortalidade, sobe ao céu e, sob a orientação de Juno, chega à Via Láctea onde se ergue o palácio de Júpiter. Aí se concentram todos os deuses e seres celestes de menor categoria, assim como as almas dos grandes vultos antigos. No auge da solenidade, levanta-se a mãe da noiva e diz a Júpiter e aos outros deuses que à vista de todos fosse entregue o que o noivo preparara para os esponsais, que se assegurassem os direitos da noiva e se procedesse à leitura das tábuas do dote e da lex Papia Poppaeaque. Surge, então, Febo com os presentes do noivo, sete fâmulas que são as sete Artes: Gramática, Dialética, Retórica, Geometria, Aritmética, Astronomia e Harmonia.

(1). - Martianus Capella, De Nuptiis Philologiae et Mercurii Libri IX Edidit Adolfus Dick. Addenda adiecit Jean Préaux. Stutgart, Teubner, 1969. Cf., pág. 41 . 
A medida que Febo apresenta as donzelas. cada uma vai desfiando num discurso o essencial da sua arte. Aliás, os nove Livros das Núpcias de Filologia com Mercúrio se iniciam cada um com uma poesia que contem o tema a ser desenvolvido de seguida em prosa. Trata-se do gênero chantefable que se tornará típico na Idade Média, isto é, a mistura de prosa e verso numa obra.

Marciano Capela descreve o aspecto e as insígnias de cada uma das Artes, de tal forma que suas descrições se tornaram modelos consagrados para os escultores e pintores da Idade Média, ao passo que a sua obra, animada nos dois primeiros livros, mas árida nos sete restantes, se tornou a obra por excelência a respeito das sete artes liberais.

A Gramática (livro III) apresenta-se como uma velha senhora, descendente do rei Osiris, de Menfis, tendo passado grande parte de sua vida na Ática; surge revestida com uma manto romano (penulata). Traz um estojo de marfim com tinta, penas, tabuinhas e férula, sendo esta para castigar os alunos indóceis. Alem disso, trazia um escalpelo para intervenções cirúrgicas na língua e nos dentes, a fim de cortar os vícios da linguagem e, ainda, uma lima dividida por traços doirados em oito partes, símbolos das oito divisões do discurso.

A dialética (Livro IV), de rosto fino e olhos vivos, traz os cabelos enrolados a cairem por degraus até aos ombros. Tem na mão esquerda uma serpente meio oculta pelo vestido e na direita uma tabuinha de cera e um anzol. As inscrições gravadas nessa tabuinha denunciam as insídias viperinas ocultas em sua mão esquerda.

A Retórica (Livro V) apresenta-se como a virgem mais imponente, de grande estatura, esbelta e linda. Armada como um guerreiro, marcha ao som de trombetas. Em seu peito refulgem pedras preciosas e no seu séquito nota-se a presença de Ésquines, Isócrates e Lísias, e de muitos outros ilustres representantes da eloquência e das letras.

A Geometria (Livro VI) comparece como uma formosa mulher trajada com belíssimo vestido em que estão desenhadas as formas, os movimentos dos astros e a sombra da terra no céu. Geometria tem na mão direita um compasso (radius) e na esquerda, uma esfera.

Aritmética (Livro VII) surge a fazer um discurso em que se enaltece como a fonte primacial de todas as coisas, singulos vos universos que recenseam ex meis ramalibus germinari. Sua cabeça resplandece de modo impressionante. Da fronte escapa alvinitente raio, do qual logo sai um segundo, mais um terceiro, um quarto, até que se multi- 
plicam de modo inumeravel para retornarem, enfim, à unidade inicial. Seu vestido variegado e pluriforme devido à representação de obras de toda a natureza, estava recoberto por uma capa. Seus dedos moviam-se incessantemente numa agitação semelhante à dos vermes (vermiculati) .

O aparecimento de Astronomia (Livro VIII) perante o divino Concílio foi dos mais esplendorosos. Ela surgiu inscrita num globo de fogo com uma coroa de estrelas sobre os cabelos cintilantes e com duas grandes asas doiradas, com penas de cristal. Numa das mãos trazia um brilhante instrumento de um côvado de altura, e na outra um livro em que se divisam os caminhos dos deuses e os cursos dos astros.

Finalmente (Livro IX), desponta a sublime Harmonia entre Febo e Palas Atena, e cuja sonora cabeça era coberta for folhas de ouro coruscante. Seu vestido de lâminas retinia ao menor movimento, de tal modo que ela era melodiosa da cabeça aos pés. Entrou em cena com um cortejo das deusas Peta, Volúpia e as Graças, e de poetas e músicos como Orfeu, Anfião e Arião, enquanto à esquerda e à direita marchavam muitos heróis e sábios de longa cabeleira. Com a mão direita Harmonia extraia admiráveis acentos das cordas sonoras de um grande escudo de ouro, enquanto da esquerda pendiam pequenas efígies doiradas como símbolos dos prazeres teatrais.

Essas, as sete figuras de mulheres esplendorosas com que a imaginação de Marciano Capela povoou a mente dos estudiosos na Idade Média e, através da influência exercida sobre os artistas, as fachadas das catedrais.

Parece-me conveniente destacar alguns aspectos interessantes dessa obra de Marciano Capela. Primeiramente, atente-se para o seu carater geral: o conúbio de Mercúrio com Filologia. Como diz Plotino, quando os sábios antigos representavam simbolicamente a Hermes com um orgão gerador sempre em atividade, eles queriam dizer que Hermes - ou Mercúrio - gerador das coisas sensíveis, representa o noêtos lógos, a razão inteligivel (2). Daí para Marciano Capela a conveniência da união de Mercúrio - lógos - com Filologia filein lógos - o amor à razão.

Em segundo lugar, convem assinalar que Mercúrio é um deus bem falante, patrono da eloquência. Nada mais indicado que a sua

(2) . - Plotin, Ennéades III, 6, 19. Ed. Brehier, Paris, Les Belles Lettres, 1956, pág. 122. 
união com Filologia, paradigma do pensamento claro e da linguagem expressiva, a macilenta perscrutadora do cosmos e a estudiosa afeita às vigílias sobre os livros, conforme o elogio que the teceu Juno (3). Ao lado dessa aclamada e venturosa Filologia, a figura de Filosofia encolhe-se e apaga-se, claro sinal da decadência dos estudos filosóficos no século V, no Império Romano moribundo. Filologia representa o triunfo e o enaltecimento do ideal retórico. Com as suas sete serviçais, que são as Artes Liberais, ela oferece aos homens a suma dos conhecimentos. Desse modo, Filologia representava para o orador o supremo ideal da cultura, tal como este fora concebido por Cícero (4) .

Outro ponto interessante na obra de Marciano Capela acha-se no segundo livro, quando Filologia vomita uma biblioteca. Diz, então o autor que os livros iam sendo recolhidos por várias donzelas, quarum Artes aliae, alterae dictae sunt Disciplinae. Ora, como o próprio Marciano frisa, algumas dessas jovens eram Artes e as outras, Disciplinas. Qual seria a razão dessa distinçăo? Cícero, por exemplo, usava indiferentemente uma expressão por outra, ao referir-se às artes, artes liberales, ingenuae, bonae artes, bonarum rerum disciplinae, etc. No século IX, Remi de Auxerre, ao comentar esse passo das Núpcias de Filologia com Mercúrio, explica que a diferença entre arte e disciplina reside no seguinte: há disciplina, quando se aprende, cum discitur, e arte, quando se chega ao perfeito hábito da alma, isto é, à inteligência (5). Santo Isidoro de Sevilha, no começo do século VII, já chamara a atenção para tal distinção na sua obra Etymologiae Sive Origines com observar no início do Livro I que Platão e Aristóteles haviam estabelecido tal diferença, ao reconhecerem que a arte se refere a coisas que são de um modo, mas podem ser de outro, enquanto a disciplina trata de coisas que não podem ser de outro modo. Assim, quando se afirma algo de verdadeiro após várias discussões, trata-se de disciplina, e quando se trata de algo que é apenas objeto de opinião ou só algo verossimil, então temos a arte (6).

(3). - Ib. lib./, pág. 23.

(4). - Cicero, De Oratore, Lib./, VI, 2) (ed. Loeb Classical Library, vol. I, pág. 16).

(5). - Remigii Autissiodorensis Commentum in Martianum Cappellam, Lib. II. Ed. Cora Lutz, Leiden, E. J. Brill, 1962, vol. 1, pág. 175.

(6). - Isidori Hispalensis Episcopi Etymologiarum sive Originum Libri $X X$. Ed. Lindsay, Oxford University Press, 1966, Tomus $I$.

Aludimos a este trecho do Santo Isidoro, porque as suas Etymologiae constituiam obra de consulta obrigatória nas escolas, a enciclopédia que resolvia as dúvidas dos estudiosos. Na verdade, porem, essa distinção entre arte e disciplina ele a copiou de Cassiodoro que a examina em dois lanços das suas Institutiones, a saber, ao tratar da Retórica no Liber II, II, 17, e da Dialética no mesmo Liber II, III, 20. Cf. Cassiodori Senatoris Institutiones. Edited from the Manuscripts by R. A. B. Mynors. Oxford, At the Clarendon Press, 1961, pág. 108 e 130. 
Releva, tambem, anotar a declaração de Marciano Capela de que a dialética foi divulgada pela primeira vez em língua latina graças ao trabalho de Marco Terêncio Varrão, de quem se reconhece devedor.

Alem de tudo isso, vale a pena destacar os louvores que Aritmética teceu ao número sete, ao observar que é o símbolo de Minerva, que sete são os círculos e os planetas, as misturas dos elementos, os orifícios da cabeça que servem de orgão dos sentidos, os membros vitais: língua, coração, pulmão, o baço, o fígado e os dois rins. Facilmente se infere, dado o simbolismo desse número, a razão de serem sete as artes liberais.

Por último, lembremòs apenas que a primeira parte do Livro VI, Geometria, contem um tratado de geografia e que, no começo do último Livro, Marciano Capela explica a exclusão, em sua obra, da Arquitetura e da Medicina, as duas artes que apareciam na lista das Nove Disciplinas de Varrão. Trata-se, diz o retórico africano, de duas artes muito terrenas, que nada tinham a fazer na amplidão do ceu, perante o senado celeste reunido na Via Láctea.

A obra de Varrão não chegou até nós. A de Marciano Capela, embora não seja quase lida, foi a base do ensino das escolas medievais, com o programa das artes sermocinais do trivium: gramática, retórica e dialética, e das artes reais do quadrivium: aritmética, geometria, astronomia e música. Nesses dois grupos das sete artes estava o fundamento da clássica divisão das matérias do ensino em letras e ciências.

\section{I}

\section{CONCEPÇÃO ANTIGA E MEDIEVAL DAS ARTES LIBERAIS.}

No ano de 594, no início do período medieval, Gregório de Tours, ao terminar a sua História dos Francos, dirige-se aos seus futuros sucessores na cátedra episcopal de Tours, conjurando-os a que não destruam nem alterem as suas obras, ainda que lhes pareçam escritas em estilo pesado, impressão que seria de esperar de qualquer bispo bem exercitado nas sete artes liberais, e, que nelas se tivesse iniciado sob a orientação do "nosso Marciano".

Essas palavras de Gregório de Tours a respeito da formação dos eclesiásticos são bem esclarecedoras a respeito do papel nela desempenhado pelas Núpcias de Filologia com Mercúrio do "Martianus noster". Qual era, entretanto, o significado e o alcance escolar dessa obra, ou melhor, das próprias sete artes liberais, de acordo com a mundividência cristã que plasmou a Idade Média? 
Examinemos, primeiramente, a posição dos estudos liberais no mundo antigo. Platão, já o vimos no parágrafo anterior, distinguiu entre as logikai teknai e as banausoi teknai, isto é, as artes racionais próprias de um homem livre, e as artes mecânicas, impróprias para um cidadão. Aristóteles, no Livro VIII da Política, observa, ao tratar da educação dos jovens, que são mecânicas e envilecedoras todas as artes que incapacitam o corpo, a alma ou a mente dos homens livres para a prática e as atividades da virtude. Entram na mesma categoria das bánausoi téknai todos os trabalhos assalariados, uma vez que impedem a mente de desfrutar do lazer, e a degradam. Essas considerações, como diz o Filósofo, obedecem ao princípio estabelecido sobre a distinção entre os ofícios ou serviços eleutheroi ou aneleutheroi, liberais e iliberais ou mecânicos. Esse princípio, por sua vez, prendia-se à crença antiga de que os escravos não passam de instrumentos a serviço dos homens livres, e de que há homens que nascem para a escravidão ou são naturalmente escravos, se, desde o nascimento, são dotados apenas de força física, mas não são dotados de inteligência ou se mostram incapazes de se dirigirem por ela. Debalde se fizera ouvir alguma voz contrária a essa crença que servia de base à organização social do mundo clássico. O sofista Antifonte, por exemplo, declarava que os gregos respeitavam e veneravam quem era de origem nobre, mas não respeitavam nem honravam quem fosse de nascimento obscuro. E nisso, exclamava, comportamo-nos uns para com os outros como bárbaros, porque, por natureza, todos somos absolutamente iguais, quer gregos quer bárbaros (7).

Cícero, entre os romanos, admitia serenamente que o escravo não passa de um instrumento falante, ao mesmo tempo que distinguia as artes liberales ou ingenuae $e$ honestae das outras artes sordidae ou inhonestae (8).

Quem, porem, entre os romanos, definiu melhor o significado das artes liberais foi Sêneca. Na famosa Epístola 88, o Cordovês explica que a gramática, a geometria, a música, a aritmética e a astronomia são estudos liberais, porque são dignos de um homem livre. As artes liberais, acrescenta, não levam à virtude mas preparam o caminho para ela; não a ensinam, mas dispõem a alma para a receber. Sêneca declara concordar com Posidônio quanto à classificação das artes em quatro espécies: vulgares ou sórdidas, recreativas, pueris e liberais. As primeiras são os ofícios manuais exercidos pelos trabalhadores; as se-

(7). - Hermann Diels, Fragmente der Vorsokratiker, Weidmannsche Verlagsbuchhandlung, 1956. Vol. II, pág. 352-353.

(8). - Cicero, De Officiis, 1, 42. Ed. C. Atzert, Leipzig, Teubner, 1932, pág. 72 . 
gundas (ludicrae) têm por objetivo o prazer dos olhos e do ouvido; as artes pueris são as que os romanos chamam de liberais, enquanto as liberais propriamente ditas são as que têm por objetivo a virtude. Ora, só uma ciência, a do bem e do mal, dá à alma a perfeição e é inteiramente liberal, isto é, livre; e tal ciência é apenas a filosofia. Na Epistola 90, entretanto, Sêneca cita outra vez as opiniões de Posidônio, afirmando concordar em muitas coisas com ele, mas não em que a filosofia tenha gerado as artes que se usam correntemente na vida, pois isso equivaleria a uma excessiva concessão às artes manuais. De acordo com Posidônio, os sábios teriam inventado a arquitetura, as ferramentas, os metais, a tecelagem, a agricultura, a arte do padeiro, assim como a de construir navios, e a da pilotagem. Isso, porem, é inadmissivel, diz Sêneca. Sem dúvida, foi a razão que deu origem a todas as artes, mas no caso das artes sórdidas não se trata de obra da razão superior, recta ratio, mas apenas de descobertas do homem, e não do sábio. Todas essas coisas, assevera Sêneca com ênfase, foram inventadas pelos mais vis escravos, vilissimorum mancipiorum, enquanto a sabedoria se assenta bem mais alto, não ensina as mãos, mas só é mestra das almas. Por isso, se os sábios estão afastados das baixas ocupações manuais, isso não ocorre, como pensa Posidônio, devido a uma separação entre os sábios e as artes que criaram para utilidade da vida. Entre o sábio e os ofícios manuais, continua o filósofo, o que existe é completa incompatibilidade, ad illas omnino non venit (9).

Como se pode facilmente comprovar, nem a concepção escravagista da sociedade nem o sobranceiro desprezo das artes mecânicas se compadecia com o Cristianismo. E preciso, entretanto, não olvidar que a Idade Média herdou a cultura retórica dos Romanos, e que o instituto da escravidão permaneceu como situação social que a própria Igreja encarava como um fato inevitavel, embora não aprovasse a sua justificação. No ano 817, Agobardo, arcebispo de Lião, escrevia a Luis, o Piedoso, ressaltando que

"a mesma fé foi ensinada por Dius, a mesma esperança, espalhada pelo Espírito Santo no coração dos crentes, assim como a mesma caridade, a mesma vontade, o mesmo desejo e a mesma oração. Quaisquer que sejam as suas diferenças étnicas, a diversidade da sua condição, dos sexos, de nascimento, nobres ou servos, todos os homens não invocam senão um só Pai... Ó celeste fraternidade, ó concórdia sempiterna, ó unidade indissoluvel, obra de um só aułor; por vós os céus se alegram, exulta a terra, mo-

(9). - L. Annaei Senecae Ad Lucilium Espistulae Morales, ed. Achillas Beltrami, Roma, Typis Publicae Offcinae Polygraphicae, 1949, vol. II, pág. 24. 
ve-se o mar, rejubilam os campos e tudo o que neles existe, e que todas as nações aplaudem. E com razão, porque todos, feitos irmäos, o servo e o senhor, o pobre e o rico, o ignorante e 0 sábio... o humilde artesão e o sublime senhor, invocam um só Deus, o Pai" (10).

Por outro lado, quando Santo Agostinho, no primeiro quartel do século V, se refere no De Doctrina Christiana às artes mecânicas, não as trata com o tom de superioridade dos aristocratas antigos. Ao contrário; observa que durante a vida o estudioso deve tomar um conhecimento ligeiro e superficial dessas artes, não para as praticar, mas para poder aprecia-las e para poder entender o que diz a Sagrada Escritura ao recorrer a elas em expressões figuradas, a não ser, esclarece ainda o santo doutor, que o dever nos obrigue a emprega-las.

Alem disso, é preciso frisar que os mestres cristãos procuraram despojar o termo liberal da sua conotação social. Assim, Cassiodoro, no prefácio do Livro II das suas Institutiones explica a origem da expressão liberal, dizendo que a palavra liber procede de "libro" (ablativo de liber) que significa a casca da árvore, destacada e libertada do tronco, e sobre a qual, antes da descoberta do papel, os antigos redigiam os seus versos (11). Séculos mais tarde, na duodécima centúria, João de Salisbury declarava, por sua vez, no Metalogicus que as artes foram chamadas de liberais pelos antigos, tanto porque eles cuidavam de nelas instruir os próprios filhos - e em latim, liber, liberi significa filho - como, tambem, porque o seu objetivo é proporcionar ao homem a libertação dos cuidados que lhe impediriam a consagração à sabedoria. Ademais, elas nos livram muitas vezes das necessidades, até mesmo materiais, de tal modo que a mente dispõe, ainda, de maior liberdade para poder aplicar-se à filosofia (12).

Todavia, durante a Idade Média, sobre serem as artes liberais consideradas como meio de que dispõe os homens para desbastar a ignorância, foram elas tomadas como partes da filosofia e vias de acesso à sabedoria superior da Sagrada Escritura. Essa função ancilar das sete artes quanto aos Livros Sagrados foi determinada primeiramente, no início da era cristã, pelo sábio judeu Filão de Alexandria . Filão colocou-se como pensador e crente diante do problema das relações da filosofia com a revelação das Escrituras, e concluiu que os

(10) - Agobardus, Liber adversus legem Gumdobaldi, in Migne PL, 104, cl. 113 e seguintes.

(11). - Cassiodorus, Institutiones. Edited from the Manuscripts by

R. A. B. Mynors. Oxford, At the Clarendon Press, 1961, pág. 91.

(12) - Ioanes Saresberiensis, Metalogicus, Lib. I, Cap. XII, in Migne, PL, t. 199, cl. 839 C. 
estudos elementares das artes liberais são como a escrava Agar a serviço de Sara, isto é, da virtude pregada pelos Santos Livros, e com a qual se deve casar legitimamente o intelecto representado por Abraão (13).

Essa concepção filoniana, que faz da filosofia doulê sophias, a escrava da sabedoria, transmitiu-se na escola cristã de Alexandria aos meio de suas obras, através da Idade Média. Orígenes, por exemplo, meio de suas obras, atraves da Idade Média. Orígenes, por exemplo, na sua curta mas incisiva Carta a Gregório Taumaturgo, espera que este tome da filosofia grega tudo o que possa servir de ensino encíclico ou propedêutico à doutrina cristã. E assim, concluiu,

"o que os filósofos dizem da geometria e da música, da gramática, da retórica e da astronomia, chamando-as de auxiliares da filosofia, nós a aplicaremos à própria filosofia em relação ao Cristianismo" (14).

Essa idéia, prossegue, ainda, Orígenes, é sugerida por uma passagem do Exodo, na qual (Exodo, 11, 2, 12, 35) o próprio Deus ordena que os judeus, com os despojos dos egípcios - vasos de prata e de ouro, vestimentas - fabriquem os objetos necessários ao culto divino. Esse tema dos "despojos dos egípcios" será tomado ao pé da letra durante a Idade Média, e a começar, em grande estilo, por Santo Agostinho, desde o fim do mundo antigo. No De Doctrina Christiana, Santo Agostinho traça o programa de estudos para o jovem estudioso cristão. Especialmente no Livro II, o santo doutor insiste na idéia de que o estudo proveitoso da Sagrada Escritura requer o conhecimento das artes liberais, de línguas estrangeiras como o grego e o hebraico, da história, e até mesmo das artes mecânicas. Tudo é como o ouro, a prata e as vestimentas possuídas pelos pagãos. Mas, quando o cristão se afasta sinceramente da sua sociedade infeliz, deve arrebater-lhes esses bens, o ouro e a prata, para o uso justo da pregação do Evangelho, assim como deve converter em uso cristão a sua vestimenta, isto é, suas instituições puramente humanas, mas proveitosas à sociedade e de que não podemos carecer na vida presente.

(13). - Philo, De congressu eruditionis gratia (The Loeb Classical Library), with an English Translation by Colson and Whitaker. - London, William Heinemann, 1949. Vol. IV, pág. 458-551.

(14). - Origenis, Epistola ad Gregorium, in Migne P. G., t. 11, cl. 87-92. - Grégoire Le Thaumaturge, Remerciement a Origène - Lettre d'Origène à Gregoire (Sources Chrétiennes. 148). Paris, Les Éditions du Cerf, 1969, pág. 186. 
Nessa antiga perspectiva escolar que remota a Filão de Alexandria, Santo Agostinho orientou definitivamente o espírito da escola medieval, especialmente até ao Renascimento do século XII, quando tal concepção começou a entrar em colapso, devido ao aumento do saber e à transformação da mentalidade que se processou conjuntamente com as grandes mudanças sociais daquela época.

\section{I I}

\section{OS ENSINAMENTOS DA LITEIRA DA FILOLOGIA.}

Um dos resultados do progresso intelectual e do desenvolvimento da filosofia através dos séculos foi a convicção de que existem várias espécies de saber, já que o homem é incapaz de abarcar todo o domínio do cognoscivel com o poder do seu intelecto que não consegue apreender de uma só vez e simultaneamente todas as perspectivas possíveis do conhecimento. Por isso, apesar de raras e afônicas discrepâncias, é fluente e constante a distinção entre os níveis ou modalidades do saber, isto é, o conhecimento vulgar e ingênuo, o científico, o filosófico e o religioso. Pode afirmar-se que, desde épocas remotas, os estudiosos souberam discernir o conhecimento popular ou ingênuo do filosófico ou científico, ainda que não pudessem distinguir entre as modalidades científica e filosófica do conhecimento, e embora nem sempre usassem expressões linguisticamente determinadas para o tipo vulgar e o filosófico. Sabiam, porem, que certas coisas se conhecem, ao mesmo tempo que se justificam racional ou empiricamente, enquanto outras se presumem conhecer mas sem que se possa apresentar uma justificação convincente. Ocorria, entretanto, que desde as civilizações mais antigas os conhecimentos de tipo filosófico, científico e religioso se interpenetravam. Assim, no antigo Egito os conhecimentos médicos misturavam-se com as noções supersticiosas da magia, de modo que noções exatas de anatomia e de fisiologia vinham a confundir-se, especialmente no nivel da terapia, com as abusões ridículas das práticas mágicas. Da mesma forma, as elevadas noções matemáticas dos Pitagóricos eram ensinadas de mistura com a arbitrária mística dos números. De fato, durante a idade antiga, os estudiosos em geral não souberam distinguir os níveis de conhecimentos que hoje conceituamos e denominamos de científico, filosófico e religioso, embora os gregos aludissem muitas vezes ao carater racional do conhecimento filosófico, como se pode verificar especialmente nas obras de Platão e de Aristóteles.

$\mathrm{Na}$ verdade, o estudo paciente da história do pensamento acaba por revelar que a distinção entre o conhecimento filosófico e religioso só 
se afirmou, sem margem de duvida, a partir do século XIII, quando São Tomás de Aquino estabeleceu com segurança e tranquilidade, que a filosofia é conhecimento puramente racional, de ordem natural, que se alcança através da reflexão, enquanto o conhecimento teológico ou religioso se baseia numa revelação divina e é de ordem sobrenatural, dependendo a sua admissão, por parte do estudioso, de um ato de fé, pelo qual ele reconheça a procedência das verdades que constituem os princípios fundamentais do conhecimento religioso, ou seja, da teologia.

Quanto ao conhecimento científico, esteve por muitos séculos ligado ao filosófico, de tal modo que certas pessoas, diante do espetáculo da constituição moderna das ciências autônomas, concluiram apressadamente que a filosofia acabaria por se esvaziar, à medida que se prolongasse a evolução do conhecimento científico. Pura ilusão, de vez que o progresso das ciências não empobrece a filosofia, mas, ao contrário, a enriquece, já que ela se despoja de uma vegetação luxuriante que muitas vezes sufocava as suas próprias flores e frutos, a própria essência do saber puramente racional, crítico, argumentativo e universal. Note-se que, ainda no início do século XIX, Lamarck designava a sua obra científica como Filosofia zoológica, tal como já se falara anteriormente de Filosofia química. Na verdade, do fim do século XIX para cá é que se tem frisado a distinção real entre filosofia e ciência. O homem consciente das suas conquistas intelectuais através dos tempos sabe que existem diferentes tipos do saber, através dos quais ele procura apropriar-se da inteligibilidade do real, e apreender o significado das coisas para orientar a sua conduta no mundo, para viver e ser feliz.

Antes de terminar o mundo antigo, a confusão entre filosofia e religião acentuou-se ainda mais do que em épocas anteriores. No século III, principalmente, junto com a proliferação dos cultos orientais dos deuses egípcios Isis e Serapis, e frígios, Mitra, Cibele e Atis e junto com a floração da feitiçaria e da magia, articula-se a filosofia de Plotino de feição essencialmente religiosa, de tal forma que, no dizer de Inge,

\footnotetext{
"a filosofia se tornara a expressão intelectual da religião pessoal" (15).
}

Com esse precedente do que se poderia chamar de filosofia profana, não é de admirar que muitos cristãos considerassem a religião co-

(15). - Inge, W. R., The Philology of Plotinus, Third Edition. London, Longmans, Green and Co., vol. I, pág. 36 . 
mo filosofia ou usassem desta expressão para denominar a própria crença. O filosófo alardeava saber o caminho da vida feliz, e procurava, na linha do estoicismo, assegura-la por meio da prática da virtude. Era, por conseguinte, mestre do pensamento e mestre de moral, um homem que refletia sobre o significado da vida, sondava 0 curso dos astros e investigava quais fossem as regras que deviam reger os atos humanos.

Nessa época em que se inicia o ocaso do mundo antigo, já se estabelecia nítida diferenciação entre filosofia e filologia. Etimologicamente, a filologia seria o amor à razão, e a filosofia, o amor à sabedoria . $\mathrm{Na}$ prática, como Wilmann observou muito bem, havia quase uma equivalência entre filologia e polimatia, ressaltando-se que a filologia designaria no período helenístico o interesse cultural que se satisfazia nos livros, enquanto a polimatia consiste no desejo de aprender muitas coisas, tanto através dos livros, como por outros meios: observações, conversas, viagens, explorações, etc. (16). A filologia, entretanto, vinha a ser uma espécie de coroamento dos estudos encíclicos por um lado, mas, por outro, servia de grau de acesso para a mais alta forma de saber que era a filosofia.

De acordo com Suetônio, a primeira pessoa que reivindicou o título de filólogo foi Erastótenes, e logo outras passaram a adotar essa denominação, devido ao significado que ele the atribuira, o de homem erudito, isto é, possuidor de

$$
\text { "múltiplos e variados conhecimentos" (17). }
$$

A filologia, portanto, equivaleria, a bem dizer, à erudição livresca, mas com uma conotação que the adveio da frequentação dos retóricos. O filólogo era um erudito que se comprazia em analisar e interpretar as obras de vário teor, máxime as literárias. A filologia, desse modo, caracterizou-se, desde o período helenístico, como crítica erudita, que exigia dos seus cultores a reflexão característica dos filósofos e a bela elocução própria dos hábeis retóricos. Não admira que se tivesse erigido em ideal da formação retórica. No mesmo passo a velha polimatia, tão execrada por Heráclito, passava a ser absorvida pela filosofia, como se depara em Aristóteles que toma a filosofia como um saber universal, ao dizer que concebe o filósofo como homem

(16). - Willmann, O. - Didaktik als Bildungslehre. Freiburg-Basel-Wien, Herder, 1957, pág. 110.

(17). - Suetonius, De Grammaticis, $\mathrm{X}$, in Suetonius (The Loeb Classical Library). Translation by J. C. Rolfe. London, W. Heinemann, -1950 , vol. II, pág. 410 . 
que possui a totalidade do saber, isto é, que conhece todas as coisas (epístasthai), tanto quanto possivel, mas sem ter o conhecimento de cada uma delas em particular (18).

O conflito entre filósofos e filólogos já se evidencia pelo fim do primeiro século de nossa era. Numa de suas magníficas Cartas a $\mathrm{Lu}$ cílio mostra Sêneca o modo como se devia escutar as lições dos filósofos. Ninguem, diz Sêneca, frequenta um filósofo sem se tornar melhor ou disposto a melhorar, tal como ninguem se expõe ao sol, ainda que não tenha a intenção de tomar um banho solar, sem que não acabe queimado assim como quem se demora a visitar um fabricante de perfumes acaba por se retirar exalando um bom odor. No entanto, observa, há duas espécies de pessoas que frequentam os filósofos e não se tornam melhores e, portanto, não aproveitam as aulas de filosofia: os que permanecem durante anos como alunos, mas que não são discipulos e sim inquilinos dos filósofos, e os que se comportam simplesmente como ouvintes, que só apreciam o prazer de escutar as explanações ou só se deixam embalar pela beleza do estilo. Os ouvintes da primeira classe estão fora das nossas cogitações. Os da segunda, ainda se destacam por prestarem atenção ao significado das palavras e das sentenças, mas seu interesse para aí. A culpa é dos seus professores, principalmente, que só ensinam a discutir e não a viver, mas cabe, tambem, aos discípulos que trazem para os mestres, não uma alma para ser cultivada, mas apenas o engenho. "Desse modo, aquela que foi filosofia transformou-se em filologia", itaque quae philosophia fuit, facta est philologia. Por isso, aconselha Sêneca, no estudo da filosofia deve-se voltar a atenção para o objetivo da vida feliz, e não para os arcaismos e neologismos, metáforas inadequadas ou figuras de estilo, com olhos de filólogo ou gramático (19).

Todavia, apesar das advertências de Sêneca, a escola romana consagrou na teoria e na prática o ideal retórico da filologia. Embora o orador na concepção de Cícero e de Quintiliano devesse ser um homem de boa formação moral, de conduta reta e dotado de amplos conhecimentos, a oratória não consistia apenas em ensinar, mas tambem, em deleitar e comover os ouvintes. Para poder alcançar esse objetivo, como o representou tão bem Marciano Capela, convinha sobremaneira a união de Filologia com Mercúrio, isto é, a união da razão ou pensamento com a eloquência ou a boa e bela expressão. No livro II das Núpcias de Filologia com Mercúrio descreve Marciano Capela

(18). - Aristotle, The Metaphysics (The Loeb Classical Library). Translation by H. Tredennick. London, W. Heinemann, 1947, vol. I, pág. 8.

(19). - Sêneca, Ad Lucilium Epistulae Morales. Ed. Achilles Beltrami, Impressio altera, Roma, Typis Publicae Officinae Polygraphicae, 1949, vol. II, Ep. pág. 172 e seguintes. 
a ascensão de Filologia à Via Láctea, sentada numa liteira conduzida por quatro carregadores. Os condutores da frente eram os dois mancebos Labor e Amor, e os detrás eram duas servas, Epimelia e Agrypnia. Qual seria o significado simbólico desses quatro condutores da liteira de Filologia? Note-se que a jovem noiva ia juntar-se pelos sagrados votos matrimoniais ao seu querido Mercúrio, quer dizer, Filologia ia ser consagrada com honras divinas como a expressão do ideal alcandorado dos estudiosos, muito acima da desditosa e secundária filosofia. Marciano designa Labor como alunum dilectum da Filologia, e esclarece que Amor não é filho de Venus impudica. No seu Comentário sobre a obra de Marciano Capela, explica Remígio de Auxerre que existiram duas Venus, uma casta e pudica, e a outra, a voluptuosa deusa dos prazeres carnais e cujo filho foi Ermafrodito. Assim, tambem, existem dois amores, um bom e pudico pelo qual se amam as virtudes e a sabedoria, e o outro, impudico e mau. Desse modo, a liteira de Filologia era conduzida na frente por Labor, isto é, o trabalho, o esforço empregado por Filologia na busca da sabedoria, e por Amor, isto é, o amor da razão e do saber. Epimẹia, por sua vez, como notou Remígio no século VIII, é o que se chama cura em latim, cuidado, empenho de aprender, de investigar, enquanto Agrypnia significa a vigília a que se entregava Filologia em suas noites de leituras e de estudos.

No século XII, Hugo de S. Vitor explica no seu Didascalicon, no fim do livro III, que o Amor e Labor levam qualquer tarefa à perfeição externa, e Epimelia e Agrypnia sugerem a secreta e interior reflexão.

De fato, posta de lado a supremacia do ideal retórico, representada na obra de Marciano Capela, só podemos apreciar o ensinamento contido na simbólica liteira da Filologia: o amor ao saber e a dedicação ao estudo exigem o amoroso empenho, o esforço persistente no trabalho, junto com a contínua atenção e cuidado às exigências do estudo, a par das renúncias que ele impõe, como ocorre frequentemente com o sacrifício do tempo que deveria ser dedicado apenas ao repouso e ao sono. Qualquer estudioso sabe disso por experiência, pois quem vive do amor ao saber viaja perpetuamente na liteira de Filologia.

\section{V}

\section{A TRADIÇÃO ROMANA DAS ARTES LIBERAIS E MARCIANO CAPELA.}

Dando-se um balanço às idéias fundamentais que nortearam os nossos parágrafos anteriores, podemos assentar como princípios ou 
idéias mestras que: 1). - as artes liberais, conforme a tradição ocidental, surgiram na Grécia; 2) . - foram transmitidas à Idade Média, de forma direta, de acordo com as fontes romanas; 3 ). - o principal agente transmissor do seu conteudo e o fixador do seu cânon foi Marciano Capela na sua obra As Núpcias de Filologia com Mercúrio; 4). - o plasmador da mentalidade escolar, segundo a qual o estudo das sete artes devia voltar-se exclusivamente para a consideração da Sagrada Escritura foi Santo Agostinho, que herdou tal orientação de Filão, através do ensinamento dos Padres da Igreja que assimilaram em Alexandria a sua doutrina; 5) . - O Cristianismo determinou a mudança imediata da acepção classista do termo liberal.

Vimos que Santo Agostinho fez os seus estudos, preparando-se para o ofício de retórico, conforme a tradição escolar romana em vigor no norte da África, no fim do século IV. Alem disso, verificamos que o santo doutor tentou escrever uma enciclopédia, isto é, uma obra sobre as artes liberais, mas que não passou, a bem dizer, do projeto, só tendo restado mesmo desse propósito o tratado sobre a música. Todavia, quem lê as obras de Santo Agostinho, logo percebe o tipo de conhecimento que possuia, e o uso que fez das artes liberais nos seus trabalhos, sobre ser o seu tratado De Doctrina Christiana um manual de introdução ao estudo da Sagrada Escritura, onde ele disserta a respeito do valor das artes e traça um programa de estudos para o jovem que aspira a adquirir boa formação intelectual e religiosa. Mas, apesar disso, não foi Agostinho o mestre das artes liberais na Idade Média, nem os outros dois famosos vulgarizadores desse ensino, aos quais ainda iremos referir-nos com mais vagar, Cassiodoro e Santo Isidoro de Sevilha, mas sim Marciano Capela que, no acertado juizo de William Stahl, foi o fundador do trivium e do quadrivium na educação medieval, e figura chave na história da educação, da retórica e da ciência (20).

Aliás, convem esclarecer que, se Santo Agostinho foi figura dominante no pensamento medieval, a sua ascendência filosófica começou a ser posta em discussão a partir do século XIII. Por maior e por mais gigantesca que se estendesse a sua sombra sobre os séculos medievais, o fato é que os doutores escolásticos descobriram logo, durante o século XIII, que a formação filosófica de Agostinho era do tipo platônico e que ele desconheceu a obra de Aristóteles, afora o livrinho sobre as categorias. Daí o choque de opiniões, no século XIII, e adiante, entre os renovadores do pensamento filosófico e os tradicionalistas que desejavam continuar a repetir os ensinamentos de Agostinho que não

(20) .- William H. Stahl, To a better understanding of Martianus Capella, in Speculum, vol. XL (1965), pág. 102-115. 
admitiam pudessem ser contestados ou substituídos. Releva, ainda, observar que muitas pessoas citam Agostinho ou falam da sua influência doutrinária, como se ele tivesse vivido durante a Idade Média, quando, na realidade, ele viveu no espaço geográfico e cultural do Império Romano, e foi, como já se observou, o "último grande homem antigo", porque, logo após a sua morte, aluiram fragorosamente as estruturas grandiosas do mundo clássico. Foi depois de Agostinho que começou a Idade Média. Ora, da verificação desse fato procede uma primeira afirmação: Agostinho não frequentou as escolas medievais nem elaborou uma doutrina típica da Idade Média, apesar de influência exercida pelo seu pensamento sobre os estudiosos desse período. Mas, se ele pertenceu à Idade Antiga, então de modo algum poderia ser tomado por um escolástico, uma vez que, segundo a convenção historiográfica, doutrinas escolásticas foram as que se elaboraram nas escolas medievais, principalmente, nas universidades, ao mesmo tempo que o método escolástico se veio plasmando lentamente desde as escolas monásticas, e tomou as feições definitivas com Santo Anselmo e Abelardo, a partir do começo do século XII, tendo atingido o seu apogeu com os grandes doutores do século XIII. Todavia, se se pretende rastrear as origens remotas da escolástica, a investigação mais séria e sensata acaba por concordar com Grabmann em que o primeiro Escolástico foi Boécio. O famoso medievalista alemão viu nos opuscula sacra de Boécio os germes da teologia escolástica, especialmente no passo em que Bcécio afirma a sua pretensão de penetrar nas profundezas da ciência divina, tanto quanto fosse dado à razão humana (21). Por outro lado, no século XII, o grande Abelardo enaltece Boécio como "o maior filósofo latino" que, através dos seus escritos originais ou das suas tradições, transmitiu aos "latinos" quase todas as disciplinas das artes liberais (22).

Só pour épater les bourgeois é que se pretenderia ver em Agostinho o fundador da escolástica. Não procede, outrossim, o argumento de que ele fundou a escolástica ao tentar aprofundar a revelação cristã por meio da reflexão ou de que simplesmente procurou pensar a revelação, pois nesse caso iríamos encontrar outros fundadores mais antigos da Escolástica, tal como Clemente de Alexandria e Orígenes.

Reatando, entretanto, o fio da meada, pode afirmar-se que Santo Agostinho se inscreve, junto com Boécio, Marciano Capela, Cassiodoro

(21). - Boethius, De Trinitate, Migne, PL 64, cl. 1249 A. "Der letzte Romer-der erste Scholastiker", o último Romano e o primeiro escolástico. Grabmann, Die Geschichte der scholastischen Methode. Graz, Akademische Druck-U. Verlangsanstalt, vol. I, - pág. 148.

(22). - Abaelardus, Theologia Christiana, Migne, PL 178, cl. 1165. 
e Isidoro de Sevilha, entre os transmissores da cultura antiga aos estudiosos medievais, mas que, dentre eles, "o fundador do trivium e do quadrivium na educação medieval" foi Marciano Capela. O trivium era o conjunto da gramática, retórica e dialética, enquanto o quadrivium abrangia a aritmética, a geometria, a astronomia e a música. Na sua obra Marciano Capela fixou em sete o número dessas disciplinas, excluindo do seu âmbito a medicina e a arquitetura, que Varrão e outros escritores romanos, que trataram das artes, incluiam no elenco da enkíklios paidéia, isto é, no rol das disciplinas que compunham a educação geral, de acordo aliás, com a tradição helênica. Alem disso, Marciano Capela conseguiu elaborar um manual de tamanho razoavel, com a apresentação sucinta das sete artes .

$\mathrm{Na}$ sua Institutio Oratoria, ao se referir no prefácio ao conteudo da obra dedicada ao seu amigo Marcelo Vitório, a fim de colaborar na educação do seu filho Geta, diz Quintiliano que o seu livro é muito util, uma vez que, ao partir, por assim dizer, do berço da eloquência, e ao examinar sucessivamente todas as artes que podem ser de algum socorro ao futuro orador, ele se propõe conduzí-lo ao ponto culminante dessa arte da eloquência (23). Ora, depois de recomendar que a criança comece por aprender o grego e o latim, trata Quintiliano no capítulo IV do livro I, dá gramática que estuda a linguagem correta e as obras dos poetas, acrescentando que não basta, porem, ler os poetas e que é preciso recorrer a obras de outros gêneros, como as de música, astronomia, filosofia e eloquência. Mas é no capítulo X do mesmo livro I que Quintiliano indaga a respeito da necessidade do conhecimento de outras artes para o orador, de tal modo que, antes dos meninos passarem a estudar sob a orientação dos retóricos, tenham percorrido o círculo de conhecimentos que os gregos denominam enkíklion paideian, destacando a importância, para o orador, do estudo da geometria, da música, da astronomia e bem adiante, no Livro XIII, o da filosofia, sendo para lembrar ainda, que o estudo da retórica incluia a instrução na lógica ou dialética.

Sabe-se, tambem, que Marco Terêncio Varrão escreveu sobre as nove artes, isto é, as sete artes liberais, mais a arquitetura e a medicina. Ora, pouco antes do ano 27 da nossa era, no tempo de Augusto, Vitrúvio, no seu tratado De Architetura, mostra o modo como um romano culto e especializado numa das belas artes encarava as disciplinas liberais. Diz Vitrúvio no início do seu trabalho que a ciência do arquiteto depende de várias disciplinas e recebe a concurso benéfico de

(23). - Quintilianus, Institutio Oratoria, translation by H. E. Butler (Loeb Classical Library). In four volumes. London. W. Heinemann, 1935, Liber I, Prooemium. 
muitas artes, observando que, para ser um bom arquiteto, não basta o engenho sem instrução nem a instrução sem o engenho. Passa, então, a demonstrar que o bom arquiteto deve ser instruido em literatura, litteratus, habil desenhista, peritus graphidos, matemático, eruditus geometria, conhecedor da história, histórias complures noverit, estudioso da filosofia, philosophos diligenter audierit, não ignorante da medicina, medicinae non ignarus, instruido nas sentenças dos juristas, responsa jurisconsultorum noverit, e conhecedor da astronomia, astrologiam caelique rationes cognitas habeat. Por'conseguinte, não só Vitrúvio considera a sua ciência como uma das artes, como julga que o conhecimento das outras importa ao arquiteto, e entre elas, a medicina. Alem disso, ele observa que todas as artes estão relacionadas entre si, tem pontos de contacto, de tal forma que a encyclios disciplina, a educação geral, compõe-se dos membros das artes, à semelhança do corpo $(24)$.

No proêmio de seu tratado De Medicina, Celso, por sua vez, afirma que o fator mais importante para a ciência médica é a experiência, mas que o conhecimento de outras artes pode ser benéfico para a mente dos médicos, de tal modo que a contemplação da natureza das coisas, embora não forme o médico propriamente dito, non faciat medicum, torna-o mais apto e perfeito para exercer a medicina, como o comprovam os exemplos de Hipócrates, Erasístrato e outros (25). Galeno, tambem, afirma no seu livro Sobre as Faculdades Naturais que o estudante de medicina, desde a adolescência, deve deixar-se tomar pelo amor da verdade, o que, evidentemente, inclui uma curiosidade universal, ainda que deva primar pelo estudo ininterrupto, dia e noite, de tudo quanto foi dito pelos mais ilustres Antigos, especialmente no campo da arte médica, devendo, alem disso, submeter esses conhecimentos teóricos ao crivo da experiência (26).

Até mesmo o geógrafo Estrabão destaca a importância das artes para o aprendiz da geografia, chegando a dizer que o bom geógrafo precisa ser filósofo, pois este, alem de possuir muitos conhecimentos, investiga as coisas humanas e divinas, dedicando-se, ainda, à busca

(24) . - Vitruvius, De architectura. Translation by Frank Granger (Loeb Classical Library). In two volumes. London, W. Heinemann, 1955, Liber I, cap. I, pág. 6,8 e seguintes.

(25) - Celsus, De medicina, Translation by W. G. Spencer (Loeb Classical Library). In three volumes. London, W. Heinemann, 1958, - vol. I, Prooemium, \$ 47, pág. 26.

(26). - Galenus, On the natural faculties. Translation by Arthur J. Brock (The Loeb Classical Library). London, W. Heinemann, 1952, Book III, chap. X, § 179, pág. 278. 
da felicidade. Todavia, alem da filosofia que investiga a natureza das coisas e examina as condições da vida feliz, precisa o geógrafo, para o seu estudo específico, contar com uma instrução enciclopédica, tendo Hiparco destacado a imprescindivel necessidade da astronomia para a formação do geógrafo. A esse preparo obtido através da polymatheias ou instrução enciclopédica, urge acrescentar, recomenda Estrabão, a história terrestre, isto é, dos animais e das plantas, assim como tudo o que diz respeito ao mar. Por fim, a formação do geógrafo comporta, ainda, o conhecimento das técnicas, da matemática, da ciência natural (physikén) e da história.

Não era, portanto, apenas Vitrúvio que pretendia dar ao arquiteto uma sólida preparação cultural. Estrabão chega a ser mais exigente quanto à formação do geógrafo. No entanto, Cícero, ao enumerar no De Oratore as artes liberais, cita apenas a geometria, a literatura, a ciência natural, a ética e a política, enquanto Varrão adotou o elenco das nove disciplinas que foram reduzidas, como vimos, por Marciano Capela às sete artes liberais de que se nutriram os jovens das escolas monásticas e episcopais da Idade Média.

(27) . - Strabo, The Geography. Translaiton by Horace Leonard Jones. (The Loeb Classical Library). In eight volumes. London, W. Heinemann, 1949, Book I, chap. I, C1-C, pág. 2-39. 